A typical pattern that has been observed is for farmers to initially use improved veterinary services to increase the milk yield per cow. Over time, this allows farmers to accumulate funds to also increase the number of cows. This has led to increases on single farms from 35 to 90 times the level of total milk production and allowed farmers to become solvent members in the community. An economic analysis shows that the CDVS has tended to increase net farmers' income as well. More than $75 \%$ of farm families had an increase in net income, which ranged from US\$ 1.0 to 19.2 per cow per month.

A similar programme was established in the Chittagong in 2002. At the beginning, there were 70 farmers producing about 1500 litres of milk per day. Currently, the programme involves 269 farm families who collectively produce about 10000 litres/day. In addition, the CDVS developed a farmers association that bargains over milk prices with the sweetmeat industries. Previously farmers used to be exploited by the middleman and sweetmeat producers. Now that the productivity veterinary services are available and the associations bargain a good milk price, numbers of dairy farmers and farm milk production have increased.

CDVF, in collaboration with BRAC, has extended its activity to the Sirajganj District of Bangladesh by using the same model that is successful in Satkhira. The farmers association in Sirajganj was started in Aug 2009 with an initial collection of 260 litres milk. Now the association is producing 1500 litres milk daily. CDVF has received a sub-contract worth US\$33 200 from Care Bangladesh to test the Satkhira Model in the Joypurhat District of Bangladesh. Current priority is to establish 10 community-based centres and develop those to maximum revenue earning levels incorporating other services like Al, feed and drug shops and community information centres. Each CDVF centre will act as a one stop hub from where the dairy farmers can buy all necessary services.

\title{
Grass based agroecologic dairying to revitalize small family farms throughout student technical support: The development of a participative methodology responsible for 622 family farm projects
}

\author{
F. Abdon Schmitt ${ }^{1 \dagger}$, Willian Murphy ${ }^{1,2}$ and Joshua Farley ${ }^{1,2}$ \\ ${ }^{1}$ Federal University of Santa Catarina BR, GPVoisin- Pasture Outreach Program BR; ${ }^{2}$ The University of Vermont, USA
}

\section{Introduction}

Pasture-based animal production has in the last decade assumed outstanding importance worldwide (Rizzoli and Schmitt, 2007). This fact is mostly related to economic advantages, animal welfare, and ecological issues (Murphy, 1998). This tendency seems to be reinforced by growing food security concerns. Increasing social pressure has demanded organic animal products from agricultural methods that are safe, environmentally benign, and pasture-based. The viability of small family farms, through pasture-based ecological dairying, has been highlighted as a way to revitalize rural communities and so avoiding urban social problems in Brazil (Rizzoli and Schmitt, 2007). In this context the Voisin Grazing Group - GPVoisin, a Pasture Outreach Program started in Southern Brazil sponsored by farmers, students and professors (Federal University of Santa Catarina). The main goal of this group of volunteers was to make small farming viable through sustainable agricultural practices, and to make this possible by participative technical assistance from farmers and undergraduate students (Saade, 2003).

\section{Methodology}

The field work of the Extension Group (Voisin Grazing Group) is characterized by 17 main steps (1) Demand from organized groups of farmers; (2) Motivational speeches to farmers group showing results from agroecologic dairy farms; (3) Participative selection of farms to become pilot projects; (4) Detailed farm survey; (5) Topographic survey through GPS equipment; (6) Map drawing with CAD tools; (7) Field zoning; (8) Forest recovery planning; (9) Paddock layout. (10) Watering project; (11) Forage planning; (12) Economic summary; (13) Implementation schedule; (14) On-farm project evaluation with the entire family; (15) Construction of module I (30\% of the whole project); (16) Monthly pasture walk on pilot farms with whole groups; (17) Ongoing evaluation and selection of the next farms to be planned.

\section{Results}

The GPVoisin - Pasture Outreach Program has made 622 projects to small family farms in 58 municipal districts in the state of Santa Catarina since 1998. Whole farm planning has been undertaken by undergraduate students and farmers. About 48 students participated in the group activities in recent years. The group has promoted many events: 61 "pasture walks", 110 farm visits, 6 lecture courses about pasture-based

\footnotetext{
† E-mail: abdonfilho@hotmail.com
} 
dairy and 6 Farmers Meeting with over 200 small family farmers. The projects at the Associação dos Agricultores da Encosta da Serra Geral AGRECO at Santa Rosa de Lima are certified by ECOCERT DO BRASIL, producing organic dairy products for schools' organic lunches.

\title{
Conclusions
}

This program has provided undergraduate students, family farmers and communities with the opportunity to design and build, not only a new pasture-based milk production system for the different regions, but also a rural development model based on consolidated experiences. The GPVoisin - Pasture Outreach Program has helped to increase farm profitability through pasture based dairy (Rizzoli and Schmitt, 2007). Farmer quality of life has improved and rural migration has been reduced in these rural communities.

\section{References}

Murphy W 1998. Greener Pasture on Our Side of the Fence: Better Farming with Voisin Grazing Management. Arriba Publishing, Vermont USA.

Saade J. P. (2003) Grupo de Pastoreio Voisin: Metodologia de Implantação, Trabalho de Conclusão de Curso - Curso de Agronomia, UFSC Brazil.

Rizzoli A and Schmitt A 2007. Farmer's perception about the transition from conventional to pasture based agroecologic dairy. Brazilian Meeting in Systems Thinking, 25-26.

\section{Mixed grazing systems to improve production gains at pasture: a review}

\author{
D'Alexis Séverine, Mahieu Maurice and Boval Maryline ${ }^{\dagger}$
}

UR143, INRA, domaine de Duclos, 97170 Petit Bourg (FWI)

\begin{abstract}
Introduction
The frequent use of anthelmintics to limit gastro-intestinal nematodes has led to the emergence of resistance to these drugs (Jackson and Coop, 2000). Mixed grazing is an alternative system which can be used to reduce parasitism and increase meat production at pasture. Mixed grazing is common but few studies have quantified the benefits. Difficulties exist in to comparing different experiments on mixed grazing. This review will try to quantify the benefits of this strategy.
\end{abstract}

\section{Materials and Methods}

Papers found on mixed grazing were selected when they had enough precise data with the same stocking rate to compare mixed and control treatments. Twelve were used to construct a database comprising 244 lines (each one considered as a statistical unit) corresponding to various papers with several treatments.

To analyse the different papers and appraise the benefits of mixed grazing, we considered 2 criteria: the average daily gain (ADG) and the global production (GPobs). The GPobs observed in mixed treatment (M) was calculated as global production and expressed as g/d/ha: GPobs/

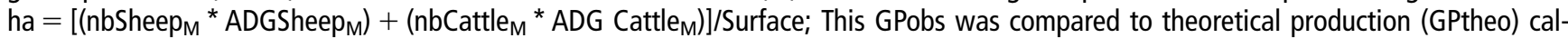
culated as production from the same number of sheep and cattle and same surface than in $M$ but with the same ADG than in control

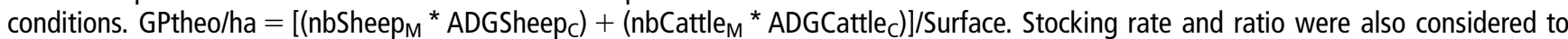
analyse the benefit of mixed grazing. In order to compare mixed grazing situations, the stocking rate was calculated by multiplying the initial bodyweight $(\mathrm{kg})$ with the number of animals per hectare and the ratio was calculated as the proportion of the weight of cattle on the total weight (cattle plus sheep) in the association, varying from 0 (sheep control) to 100 (cattle control).

\section{Results}

Mixed grazing was significant on ADG of sheep $(P=0.001174)$. The relation between the ADG and the ratio was: ADGSheep $=147+$ 0.395 * ratio (Cattle/Cattle + Sheep) $(\mathrm{SE}=0.118)$. For a ratio of $50 \%$ of cattle, the gain represented $167 \mathrm{~g} / \mathrm{d}$ that is to say a gain of $14 \%$ compared to the control $(147 \mathrm{~g} / \mathrm{d})$. There was also an effect of mixed grazing on GPobs $(P=0.0087)$ and the equation is: $\mathrm{GPobs}_{\mathrm{M}}=1579$ $+55.5 *$ ratio (Cattle/Cattle + Sheep) $-0.385 *$ (ratio (Cattle/Cattle + Sheep $))^{2}$.

For the GPtheo the relation is: GPtheo ${ }_{M}=1478+16.5 *$ ratio (Cattle/Cattle + Sheep). The gain of mixed grazing is significant with a GPobs greater by $47 \%$ compared to the GPTheo with a ratio of $50 \%$.

\footnotetext{
${ }^{\dagger}$ E-mail: Maryline.Boval@antilles.inra.fr
} 